\title{
Reaching the poor with adequately iodized salt through the Supplementary Nutrition Programme and Midday Meal Scheme in Madhya Pradesh, India
}

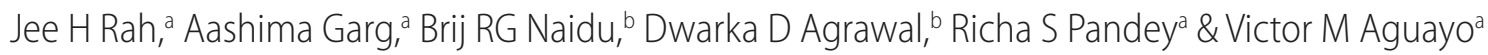

\begin{abstract}
Problem In India, adequately iodized salt needs to be made accessible to the most marginalized.
Approach In an effort to provide adequately iodized salt to the most vulnerable, in 2009 Madhya Pradesh launched a state-wide initiative through two national flagship nutrition programmes: the Supplementary Nutrition Programme of the Integrated Child Development Services and the Midday Meal Scheme. Programme staff members were taught how to correctly store salt and monitor its iodine content. Field monitors assessed the iodine content of the salt in the common kitchens of participating schools and anganwadi centres monthly. Local setting Madhya Pradesh, a state in central India, is home to a substantial proportion of India's poor. In 2009, household coverage of adequately iodized salt in the state was nearly $90 \%$ among the richest but only about $50 \%$ among the poorest.

Relevant changes Two hot meals prepared with adequately iodized salt were served daily for more than 21 days per month to approximately 89\% of the 12113584 children aged 3 to 6 years enrolled in anganwadi centres (June 2011 to March 2012). One meal on school days was served to $78 \%$ of 5751979 primary-school children and to 79\% of 2704692 secondary-school children (April 2011 to March 2012). Most of the kitchens visited in 2010 (79\%) and 2011 (83\%) were consistently using adequately iodized salt to prepare hot meals.

Lessons learnt India has large-scale social safety net programmes for the poorest. Both national and state policies should mainstream the use of adequately iodized salt in these programmes.
\end{abstract}

Abstracts in عربي, 中文, Français, Русский and Español at the end of each article.

\section{Problem}

India's salt iodization programme has a 50 year history and has made remarkable progress towards the achievement of universal salt iodization. A national policy of universal salt iodization was adopted in 1986 and subsequent legislation, both at the national and the state level, prohibits the sale of non-iodized salt for human consumption. ${ }^{1}$ Sustained efforts to ensure an adequate supply of iodized salt helped India to reach self-sufficiency in its production. ${ }^{2}$ As a result, in 2009, approximately $71 \%$ of households were consuming salt with adequate levels of iodine (i.e. $\geq 15$ parts per million). ${ }^{3}$ However, an average of 249 million Indians, including 8 million children born annually, remain susceptible to iodine deficiency disorders (IDDs). Moreover, the use of adequately iodized salt varies widely by state, from roughly $30 \%$ in Chhattisgarh to $98 \%$ in Manipur. ${ }^{3}$ Notably, coverage steadily improves as the household wealth index increases. Hence, the most disadvantaged population groups are the most susceptible to IDDs. ${ }^{3}$ For this reason, adequately iodized salt needs to be made available and accessible to the poor and most marginalized if the goal of universal salt iodization is to be met in India.

\section{Local setting}

Madhya Pradesh, located in central India, is territorially the second largest state in India and has more than 72 million inhabitants. ${ }^{4}$ The state is home to a substantial proportion of India's socially and economically deprived population. Approximately $18 \%$ and $21 \%$ of the population belong to scheduled castes and scheduled tribes, respectively, and 37\% fall in India's lowest wealth quintile. ${ }^{4,5}$ Malnutrition is prevalent. Half of the children less than 5 years of age are stunted (height-for-age $z$-score $<-2$ ) and $35 \%$ are wasted (weight-forheight $z$-score $<-2$ ) by WHO Child Growth Standards; ${ }^{6} 74 \%$ of children aged 6 to 9 months are anaemic (haemoglobin concentration < $110 \mathrm{~g} / \mathrm{l}) .{ }^{5}$ Currently, no data are available on the iodine status of the state population based on urinary iodine concentration or the prevalence of goitre, but in 2009 only $63 \%$ of households were consuming adequately iodized salt, whereas $18 \%$ were using non-iodized salt. ${ }^{3}$ Remarkably, the proportion of households using adequately iodized salt was about $50 \%$ in the lowest wealth quintile and around $86 \%$ in the highest wealth quintile.

Since Madhya Pradesh is not a salt-producing state, it imports all edible salt from the neighbouring states of Rajasthan and Gujarat. About $35 \%$ of the edible salt enters the state by rail and the remainder by road. ${ }^{2}$ This poses major difficulties because salt is monitored for adequate iodine content before shipment by rail but not before shipment by road. ${ }^{7}$ Only salt that has been adequately iodized is authorized for rail transportation, but virtually any type of edible salt can enter the state by road. In addition, inadequately iodized salt is often sold at a lower price than adequately iodized salt and is hence more attractive to many consumers, especially the poorest and the uninformed.

Poor access to adequately iodized salt, particularly among the lower wealth quintiles of the population, has prompted sustained pressure from advocacy groups demanding that the state government accelerate efforts towards attaining universal salt iodization. As a result, in 2009 the government decided to take steps towards ensuring the use of adequately

\footnotetext{
a Child Development and Nutrition Programme, United Nations Children's Fund, UNICEF House, 73 Lodi Estate, New Delhi, 110003 India.

b Women and Child Development Department, Government of Madhya Pradesh, India.

Correspondence to Jee H Rah (e-mail: jhrah@unicef.org)

(Submitted: 26 July 2012 - Revised version received: 14 December 2012 - Accepted: 11 February 2013 - Published online: 30 April 2013)
} 
iodized salt through two national flagship nutrition programmes that target the most vulnerable population groups in Madhya Pradesh: the Supplementary Nutrition Programme of the Integrated Child Development Services and the Midday Meal Scheme.

\section{Approach}

The Integrated Child Development Services, launched in 1975, provide supplementary feeding, immunization, health checkups and nutrition education to all children younger than 6 years and pregnant and lactating mothers to promote healthy child growth and development. ${ }^{8}$ All services are delivered by community-based anganwadi workers through a network of anganwadi centres (literally "courtyard shelters"), which are government-sponsored centres offering care to children and mothers. The Supplementary Nutrition Programme provides food in the form of dry takehome rations for pregnant and lactating women and for children 6 to 35 months old, as well as hot cooked meals for children between the ages of 3 and 6 years. ${ }^{8}$ The primary aim of the Supplementary Nutrition Programme is to enhance the calorific intake of children and women in low-income communities. The Midday Meal Scheme is a school meal programme providing lunch free of charge to children aged 6 to 14 years to improve children's nutritional status and enhance school enrolment and attendance. ${ }^{9}$

In general, the Supplementary Nutrition Programme and the Midday Meal Scheme operate independently. However, in 2009 the government of Madhya Pradesh launched Sanjha Chulha (community kitchen), a state-wide joint feeding programme that converged the two earlier programmes. All hot meals served at anganwadi centres and schools are now prepared in a common kitchen. Two hot meals are served daily at anganwadi centres to children aged 3 to 6 years, and one cooked meal is served to schoolchildren every school day. In addition, every Tuesday children 6 to 36 months of age, pregnant and lactating women and adolescent girls enrolled at anganwadi centres receive a hot meal. Sanjha Chulha was initiated so that instead of spending time preparing hot meals, anganwadi workers could devote more time to nutrition and health education, home visits and counselling.

In 2009, Sanjha Chulha was identified as an appropriate platform for ensuring access to adequately iodized salt for economically deprived populations. Two directives were subsequently issued - one in 2009 by the Department of Women and Child Development and another in 2011, by the Department of Panchayat and Rural Development. Both made it a requirement that only adequately iodized salt be used for preparing hot meals for anganwadi centres and schools and that only adequately iodized salt be used to prepare the dry takehome rations (mix of rice with lentils or wheat and of soya flour with Bengal gram or wheat flour) for pregnant and lactating women and young children.

District authorities began to implement Sanjha Chulha as prescribed. Programme staff were trained on the health and nutrition benefits of using iodized salt and were taught how to correctly store salt in the common kitchen and to monitor the iodine level of the salt using salt testing kits. Sanjha Chulha is supervised regularly by government officials who assess the overall implementation of the programme and test the iodine content of the salt used. In addition, field monitors sponsored by the United Nations Children's Fund test the iodine content of the salt in the common kitchen monthly. Each field monitor covers about three districts over a three-month period. A fixed number of common kitchens in each district is randomly selected for a visit during which field monitors take a random sample of salt to test its iodine content using a salt testing kit. They also monitor how the salt is stored, the type of salt packet used (preferably thick polyethylene) and kitchen hygiene.

\section{Findings}

The latest reports indicate that Sanjha Chulha has been successfully implemented in all anganwadi centres ( $n=78$ 929) across Madhya Pradesh. Between June 2011 and March 2012, 28507407 (83\%) children 6 to 35 months old who were enrolled in the anganwadi centres received one weekly take-home ration prepared using adequately iodized salt; additionally, 12113584 (89\%) children aged 3 to 6 years enrolled in the anganwadi centres received two hot meals a day that had been prepared with adequately iodized salt for more than 21 days per month. Sanjha Chulha has also been successfully implemented in all pri- mary $(n=85054)$ and secondary schools $(n=28652)$ participating in the Midday Meal Scheme. Between April 2011 and March 2012, a total of 5751979 (78\%) primary-school children and 2704692 (79\%) secondary-school children received one hot cooked meal prepared using adequately iodized salt on every school day.

The monthly monitoring data collected by the field monitors indicate that $79 \%$ and $83 \%$ of the common kitchens visited in $2010(n=1154)$ and 2011 ( $n=1096)$, respectively, were consistently using adequately iodized salt to prepare hot meals. The remaining kitchens were also using iodized salt that showed adequate iodine levels in the packaging and labelling but suboptimal levels when tested because of inappropriate salt storage methods. In such cases, programme staff members were retrained in the correct way to store iodized salt.

\section{Discussion and lessons learnt}

India's national flagship feeding programmes provide an effective delivery platform for increasing access to and use of adequately iodized salt among the most vulnerable and disadvantaged communities. The two state government directives described herein led to a change in salt procurement practices, with only iodized salt bearing a "smiling sun" logo on the package recommended for procurement. The smiling sun logo is a voluntary certification used by salt producers registered with the government to indicate that the salt has been adequately iodized. Thus, the use of adequately iodized salt in the feeding programme improved substantially after the directives were issued. A large number of preschool and school-aged children from low-income families received hot meals and women and young children received dry take-home rations prepared with salt that had been adequately iodized. Without the joint feeding programme, this segment of the population would have had little access to adequately iodized salt and would have remained at risk of IDDs. Programme sustainability is ensured because funding for the programme is budgeted under the Integrated Child Development Services project implementation plan. 
The planning and implementation of the feeding programme was fraught with challenges. Although some could be overcome, others remain. Sanjha Chulha is a feeding programme involving three different government departments in Madhya Pradesh: the Department of Women and Child Development, the Department of Panchayat and Rural Development and the Department of Education. Thus, one of the most important challenges at the outset was to convince the three different departments in the state government to issue a joint directive. This required intensive advocacy efforts based on the scientific evidence of the prevalence of iodine deficiency disorders in India and the importance of using adequately iodized salt to prevent iodine deficiency. In addition, it was not easy to achieve convergence among the three key departments, particularly in terms of fund transfers, staff training and programme monitoring. A series of joint planning and review meetings were organized in an effort to enhance collaboration and coordination among the three departments.

Given the massive scale of the feeding programme, proper monitoring and evaluation remains a major challenge. It currently focuses on monitoring

\section{Box 1.Summary of main lessons learnt}

- lodized salt has to be properly stored to maintain the optimal level of iodine, and staff should be trained accordingly.

- Efforts to create awareness in the community of the health and nutrition benefits of iodized salt should be undertaken alongside the feeding programmes.

- Programme monitoring needs to be strengthened and evaluations undertaken to generate evidence of the programme's impact on the iodine status of the target population.

coverage, iodine content, salt storage conditions and kitchen hygiene. However, the feeding programme lacks a standard monitoring mechanism for determining the actual consumption of adequately iodized salt. In addition, the limited, irregular supply of salt testing kits has hampered monitoring of the iodine content of the salt used in the common kitchens. Efforts are currently being made to improve management of the supply of salt testing kits.

Clearly, the provision of adequately iodized salt in the feeding programme needs to be accompanied by intensive community education and communication activities to generate awareness of the health and nutrition benefits of iodized salt. However, this aspect has received little attention and the educational and informational materials being used at present at the community level need to be improved.
Three important lessons have been learnt (Box 1). Over the past few decades, India has made impressive progress towards the achievement of universal salt iodization. However, reaching the last $30 \%$ of households will be difficult, since these represent the more inaccessible, socioeconomically disadvantaged households. However, effective and innovative strategies are the key to addressing the remaining challenges. India has successful large-scale social safety net programmes aimed at the most economically deprived populations. Both national and state-level policies should mainstream the use of adequately iodized salt in feeding programmes for the benefit of all, especially the most vulnerable women and children.

Competing interests: None declared.

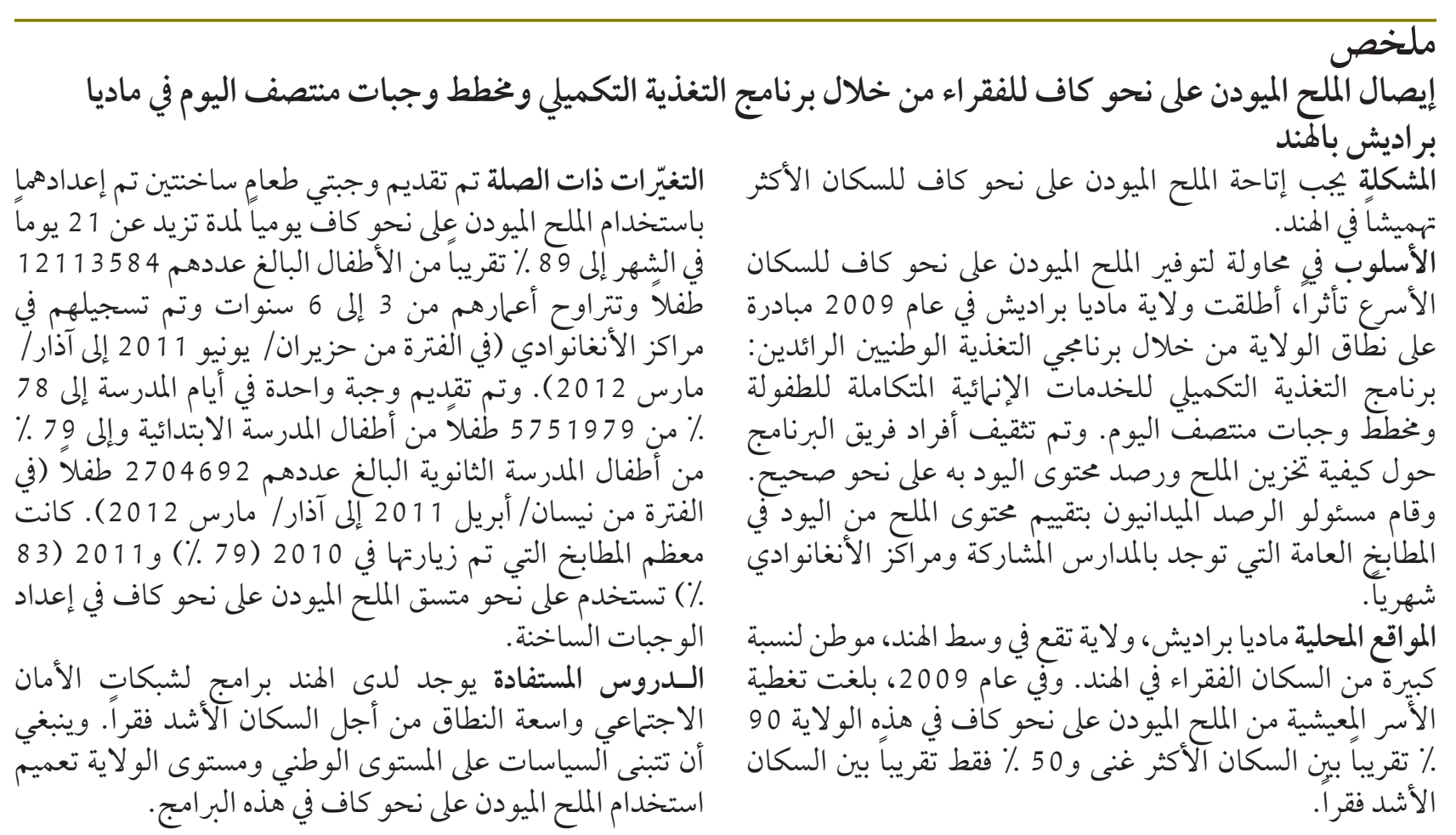




\section{摘要 \\ 印度中央邦通过补充营养计划和午餐方案向让穷人吃到磑盐}

问题 在印度, 需要让大多数边缘群体能吃到合格碘盐。 方法为了给最脆弱的人群提供合格碘盐, 2009 年中央 邦通过两个国家旗舰营养计划启动全邦范围的举措: 综合儿童发展服务的补充营养计划和午餐方案。教计 划工作人员学习如何正确存储盐和监控碘含量。现场 监测员每月评估参与学校和安哥瓦迪中心厨房的食盐 碘含量。

当地状况 印度贫穷人口有相当比例居住在中部的中央 邦。在 2009 年, 该邦合格碘盐的家庭覆盖率在最富有 人群中将近 $90 \%$, 在最穷的人群中仅有 $50 \%$ 左右。
相关变化每月超过 21 天为登记在安哥瓦迪中心总数 为 12113584 名的 3 至 6 岁儿童中大约 $89 \%$ 提供两顿 使用合格碘盐烹制的热饭菜 (2011 年 6 月至 2012 年 3 月)。为 5751979 名小学儿童中的 $78 \%$ 和 2704692 名 中学儿童中的 79\% 提供上课日的一餐饭（2011 年 4 月 至 2012 年 3 月)。在 2010 年 (79\%) 和 2011 年 (83\%) 受访的大多数欴房始终使用合格碘盐来烹制热饭菜。 经验教训印度为最贫穷的人群提供大规模的社会安全 网计划。国家和邦政策都应在这些计划中将使用合格 碘盐纳入主流。

\section{Résumé \\ Fournir un sel suffisamment iodé aux plus démunis à travers le programme de nutrition complémentaire et le système de distribution de repas scolaires au Madhya Pradesh, en Inde \\ Problème En Inde, il est nécessaire d'assurer aux populations les plus marginalisées l'accès à un sel suffisamment iodé. \\ Approche Dans un effort visant à fournir du sel suffisamment iodé aux populations les plus vulnérables, une initiative a été lancée dans tout le Madhya Pradesh, en 2009, au travers de deux programmes nutritionnels nationaux phares: le programme de nutrition complémentaire des services intégrés pour le développement de l'enfant et le système de distribution de repas scolaires. Les membres du personnel impliqué dans ces programmes ont appris à stocker correctement le sel et à contrôler sa teneur en iode. Tous les mois, des inspecteurs sur le terrain ont évalué la teneur en iode du sel utilisé dans les cuisines communes des écoles et des centres anganwadi participants. \\ Environnement local Le Madhya Pradesh, un état de l'Inde centrale, abrite une part considérable de la population démunie de I'Inde. En 2009, le pourcentage de ménages ayant accès à un sel suffisamment \\ iodé dans cet état était de 90\% parmi les plus riches, mais à peine de 50\% parmi les plus démunis. \\ Changements significatifs Deux repas chauds préparés avec du sel suffisamment iodé ont été servis tous les jours pendant plus de 21 jours par mois à près de 89\% des 12113584 enfants âgés de 3 à 6 ans inscrits dans des centres anganwadi (de juin 2011 à mars 2012). Les jours d'école, un repas a été servi à 78\% des 5751979 enfants de l'enseignement primaire et à 79\% des 2704692 enfants de l'enseignement secondaire (d'avril 2011 à mars 2012). La plupart des cuisines contrôlées en 2010 (79\%) et en 2011 (83\%) utilisaient régulièrement du sel suffisamment iodé pour préparer les repas chauds. \\ Leçons tirées L'Inde dispose de programmes de protection sociale à grande échelle pour les plus démunis. Les politiques nationales et locales doivent intégrer l'utilisation de sel suffisamment iodé dans ces programmes.}

\section{Резюме}

\section{Охват бедных слоев населения в достаточной степени йодированной солью в рамках Программы дополнительного питания и Схемы предоставления обедов в штате Мадхья-Прадеш, Индия}

Проблема В Индии необходимо обеспечить доступность

в достаточной степени йодированной соли для наиболее маргинализированных слоев населения.

Подход С целью обеспечить поставки в достаточной степени йодированной соли наиболее уязвимым слоям населения, в 2009 году штат Мадхья-Прадеш начал реализацию на всей своей территории инициативы в рамках двух национальных флагманских программ дополнительного питания: Программы дополнительного питания в рамках комплексных услуг по развитию детей и Схемы предоставления обедов. Сотрудники программы прошли обучение относительно того, как правильно хранить соль и как следить за содержанием в ней йода. Полевые наблюдатели ежемесячно оценивали содержание йода в соли на общих кухнях участвующих школ и центров «анганвади».

Местные условия В Мадхья-Прадеш, штате в центральной части Индии, проживает значительная часть бедного населения данной страны. В 2009 году охват домохозяйств в достаточной степени йодированной солью в штате был почти 90\% среди самых богатых, но всего около 50\% среди самых бедных.
Осуществленные перемены Ежедневно на протяжении более чем 21 дня в месяц два горячих блюда, приготовленных с использованием в достаточной степени йодированной соли, подавались около 89\% из 12113584 детей в возрасте от 3 до 6 лет, обучающихся в центрах «анганвади» (с июня 2011 года по март 2012 года). Одно блюдо в дни занятий в школе подавалось 78\% из 5751979 детей, обучающихся в начальной школе, и 79\% из 2704692 детей, обучающихся в средней школе (с апреля 2011 года по март 2012 года). На большинстве кухонь, посещенных в 2010 году (79\%) и 2011 году (83\%), в достаточной степени йодированная соль на регулярной основе использовалась для приготовления горячих блюд.

Выводы В Индии реализуются крупномасштабные программы по социальной защите беднейших слоев населения. В подобные программы на общегосударственном уровне и уровне штатов необходимо включить использование в достаточной степени йодированной соли. 


\section{Resumen}

\section{El acceso de los pobres a sal correctamente yodada por medio del Programa de Nutrición Complementaria y el Programa de} Almuerzos en Madhya Pradesh, India

Situación En la India, la sal correctamente yodada debe estar disponible para los más marginados.

Enfoque En su afán por suministrar sal correctamente yodada a los más vulnerables, Madhya Pradesh lanzó en 2009 una iniciativa en todo el estado a través de dos programas nacionales de nutrición principales: el Programa de Nutrición Complementaria de los Servicios Integrados de Desarrollo Infantil y el Programa de Almuerzos. Los miembros del personal que participaron en los programas aprendieron cómo almacenar correctamente la sal y controlar su contenido en yodo. Los monitores de campo evaluaron mensualmente el contenido en yodo de la sal en las cocinas comunes de las escuelas participantes y los centros anganwadi.

Marco regional En Madhya Pradesh, estado situado en el centro de la India, vive una gran parte de los pobres de la India. En 2009, la cobertura doméstica de sal correctamente yodada en el estado era de cerca del $90 \%$ entre los más ricos, pero solo de un 50\%, aproximadamente, entre los más pobres.
Cambios importantes Se sirvieron dos comidas calientes preparadas con sal correctamente yodada al día durante más de 21 días al mes a aproximadamente un 89\% de los 12113584 niños de edades comprendidas entre los 3 y los 6 años matriculados en centros anganwadi (desde junio de 2011 hasta marzo de 2012). En los días lectivos, se sirvió una comida a un 78\% de los 5751979 niños de la escuela primaria y a un 79\% de los 2704692 niños de la escuela secundaria (desde abril de 2011 hasta marzo de 2012). La mayoría de las cocinas visitadas en 2010 (79\%) y 2011 (83\%) utilizaban sistemáticamente sal correctamente yodada para preparar comidas calientes.

Lecciones aprendidas India tiene en marcha programas de protección social a gran escala para los más necesitados. Las políticas tanto nacionales como estatales deberían incorporar el uso de sal correctamente yodada a estos programas.

\section{References}

1. Ministry of Health and Family Welfare, Government of India. Revised policy guidelines on national iodine deficiency disorders control programme. Revised edition October 2006. New Delhi: MHFW; 2006. Available from: http://www. mohfw.nic.in/NRHM/Documents/revised_guidelines.pdf [accessed 21 February 2013].

2. Salt Department, Government of India. Annual report 2010-12. New Delhi: SD; 2012. Available from: http://saltcomindia.gov.in/salt-ar12.pdf [accessed 9 April 2013].

3. United Nations Children's Fund. 2009 Coverage Evaluation Survey: all India report. New Delhi: UNICEF; 2011.

4. Office of the Registrar General and Census Commissioner, Government of India. Census of India 2011. New Delhi: ORCC; 2011. Available from: http:// censusindia.gov.in/2011census/censusinfodashboard/index.html [accessed 9 April 2013].

5. National Family Health Survey (NFHS-3) 2005-6. Mumbai: International Institute for Population Sciences \& Macro International; 2007.

6. World Health Organization [Internet]. The WHO Child Growth Standards. Geneva:WHO; 2013. Available from: http://www.who.int/childgrowth/en/ [accessed 21 February 2013]

7. Sankar R, Moorthy D, Pandav CS, Tiwari JS, Karmarkar MG. Tracking progress towards sustainable elimination of iodine deficiency disorders in Bihar. Indian J Pediatr 2006;73:799-802. doi: http://dx.doi.org/10.1007/ BF02790389 PMID:17006038

8. Ministry of Women and Child Development, Government of India [Internet]. Integrated Child Development Services Scheme. New Delhi: MWCD; 2013. Available from: http://wcd.nic.in/icds.htm [accessed 9 April 2013].

9. Department of School Education and Literacy, Ministry of Human Resource Development, Government of India [Internet]. Elementary education, mid-day meal scheme. Available from: http://mhrd.gov.in/middaymeal [accessed 9 April 2013]. 